\title{
PENGGUNAAN PEMBELAJARAN MENGGUNAKAN PENDEKATAN KONSTRUKTIVISME DALAM UPAYA MENINGKATKAN KEMAMPUAN PEMAHAMAN KONSEP MATEMATIS SISWA
}

\author{
Yusfita Yusuf1, Neneng Tita Rosita2 \\ Program Studi Pendidikan Matematika \\ STKIP Sebelas April Sumedang \\ $\underline{\text { nugrahayusfita@yahoo.co.id }}{ }^{1}, \underline{\text { titayusepa79@gmail.com }}{ }^{2}$
}

\begin{abstract}
Abstrak: Penelitian ini dilatarbelakangi oleh adanya permasalahan aktivitas siswa yang kurang baik dalam pembelajaran matematika sehingga menyebabkan buruknya kemampuan pemahaman konsep matematis siswa. Oleh karena itu perlu dilakukan beberapa perubahan dalam pembelajaran matematika. Salah satu upaya yang dapat dilakukan untuk mengatasi permasalahan tersebut adalah dengan menerapkan pendekatan konstruktivisme pada pembelajaran matematika. Hasil penelitian menunjukkan bahwa kemampuan pemahaman konsep matematis siswa yang pembelajarannya menggunakan pendekatan konstruktivisme lebih baik dari pada siswa yang memperoleh pembelajaran biasa.
\end{abstract}

Kata kunci: pendekatan konstruktivisme, Kemampuan Pemahaman

Konsep Statistis

\section{A. PENDAHULUAN}

Matematika merupakan salah satu mata pelajaran yang penting pada setiap jenjang pendidikan terutama di sekolah dasar dan sekolah menengah. Hal ini terbukti dengan dimasukannya matematika sebagai salah satu mata pelajaran yang diujian nasionalkan. Matematika penting karena pengetahuan matematika akan sangat bermanfaat ketika siswa melanjutkan ke jenjang pendidikan yang lebih tinggi ataupun ketika mereka berada di tengah kehidupan masyarakat yang tidak dapat dilepaskan dari masalah-masalah matematika.

Pembelajaran matematika di sekolah akan membekali siswa pengetahuan dan keterampilan-keterampilan yang sangat bermanfaat bagi siswa. Matematika juga akan membuat siswa mempunyai kemampuan untuk berfikir logis, hal ini sejalan dengan definisi matematika yang dikemukakan oleh Johnson dan Rising (Suwangsih dan Tiurlina, 2006:4) bahwa matematika adalah pola berpikir, pola mengorganisasikan, pembuktian yang logis. Matematika itu adalah bahasa yang menggunakan istilah yang didefinisikan dengan cermat, jelas dan akurat representasinya dengan simbol yang padat, lebih berupa bahasa simbol mengenai ide daripada mengenai bunyi. Matematika adalah pengetahuan struktur yang terorganisasi, sifat-sifat dalam teori-teori dibuat secara deduktif berdasarkan kepada unsur yang tidak didefinisikan, aksioma, sifat atau teori yang telah dibuktikan kebenarannya adalah ilmu tentang keteraturan pola atau ide, dan matematika itu adalah 
suatu seni, keindahannya terdapat pada keterurutan dan keharmonisannya. Berdasarkan kutipan tersebut bahwa selain matematika sebagai suatu ilmu yang dapat melatih siswa untuk berfikir logis juga tampak bahwa matematika pada dasarnya berisi hal-hal atau konsep-konsep yang abstrak yakni berupa simbol-simbol.

Pentingnya matematika bagi siswa seharusnya menjadikan matematika sebagai mata pelajaran yang disukai para siswa. Namun pada kenyataannya banyak siswa yang menyatakan tidak suka karena mereka menganggap matematika itu sulit, membingungkan dan identik dengan angka-angka yang membosankan. Hal ini yang mungkin menjadi salah satu penyebab tingkat pemahaman konsep matematik siswa rendah. Selain dari rasa beban tersebut, rendahnya pemahaman konsep siswa juga bisa terjadi dikarenakan siswa cenderung pasif dalam pembelajaran sehingga menimbulkan kesan hanya guru yang lebih berperan aktif. Misalnya ketika mereka dihadapkan pada suatu permasalahan masih banyak siswa yang enggan bertanya kepada temannya mengenai kesulitan yang dihadapinya terlebih lagi kepada guru, yang mengakibatkan pemahaman konsep matematik mereka rendah.

Hal hal ini juga diperkuat dengan pernyataan dari seorang guru yang sekolahnya dijadikan tempat penelitian yang menyatakan bahwa dalam pembelajaran pada umumnya siswa masih lemah dalam menyelsaikan soalsoal yang berkaitan dengan mengklasifikasikan objek, menggunakan, memanfaatkan dan memilih prosedur operasi tertentu, terlebih lagi dalam mengaplikasikan suatu konsep pada pemecahan masalah. Berdasarkan hal tersebut diperlukan tindak lanjut supaya tidak terjadi kesalahan konsep pada siswa dan juga dapat meningkatkan permahaman konsep matematik siswa itu sendiri.

Salah satu upaya yang akan dilakukan berupa sebuah alternatif penyelesaian masalah dengan diterapkannya pendekatan konstruktivisme. Dengan pendekatan ini diharapkan dapat memperbaiki proses pembelajaran tersebut sehingga hasil belajar siswapun meningkat.Dipilihnya pendekatan Konstruktivisme sebagai alterantif pemecahan masalah pembelajaran di atas selain karena keunggulan-keunggulan yang dimilikinya juga karena kesesuaian karakteristik pendekatan konstruktivisme dengan permasalahan yang terjadi. Dengan pendekatan ini dalam pembelajaran diharapkan siswa dapat mengkonstruksi pikirannya sendiri dalam menemukan konsep yang dipelajari sedangkan guru berperan sebagai fasilitator dan motivator pembelajaran yang menciptakan suasana yang menyenangkan bagi siswa.

\section{B. KAJIAN TEORI}

\section{Kemampuan Pemahaman Konsep Matematis}

Kemampuan pemahaman matematik adalah sesuatu yang penting dalam pembelajaran matematika yang dalam pelaksanaanya memberikan pengertian bahwa materi yang diberikan kepada siswa tidak hanya sekedar hapalan,namun siswa dituntut untuk memahami inti dari materi tersebut. Pada intinya siswa tidak semata-mata menerima dan menghapal materi dari guru, 
namun mereka menelaah apa makna/inti yang terkandung dalam materi tersebut.

Berikut ini adalah beberapa jenis pemahaman matematik yang dirangkum oleh Sumarmo (2013: 31-32). Polya menggolongkan pemahaman matematik dalam empat tingkat pemahaman yaitu sebagai berikut.

a) Pemahaman mekanikal yaitu: dapat melaksanakan perhitungan rutin atau perhitungan sederhana.

b) Pemahaman induktif yaitu: dapat mencoba sesuatu dalam kasus sederhana dan tahu bahwa sesuatu itu berlaku dalam kasus serupa.

c) Pemahaman rasional yaitu: dapat membuktikan kebenaran sesuatu.

d) Pemahaman intuitif yaitu: dapat memperkirakan kebenaran sesuatu tanpa ragu-ragu, sebelum menganalisis secara analitik.

Skemp membedakan dua jenis tingkatan pemahaman sebagai berikut.

a) Pemahaman instrumental yaitu: hapal sesuatu secara terpisah atau dapat membedakan sesuatu pada perhitungan rutin atau sederhana, mengerjakan sesuatu secara algoritmik saja. Tingkat pemahaman ini setara dengan pemahaman mekanikal.

b) Pemahaman relasional yaitu: dapat mengkaitkan sesuatu dengan hal lainnya secara benar dan menyadari proses yang dilakukan. Tingkat pemahaman ini setara dengan pemahaman rasional.

Pollatsek membedakan dua tingkatan pemahaman yaitu sebagai berikut.

a) Pemahaman komputasional yaitu: dapat menerapkan rumus atau aturan pada perhitungan rutin atau sederhana, atau mengerjakan sesuatusecara algoritmik saja. Tingkat pemahaman ini setara dengan pemahaman mekanikal dan pemahaman instrumental.

b) Pemahaman fungsional yaitu: dapat mengkaitkan sesuatu dengan hal lainnya secara benar dan menyadari proses yang dilakukan. Tingkat pemahaman ini setara dengan pemahaman rasional dan pemahaman relasional.

Copeland menbedakan dua tingkatan pemahaman yaitu sebagai berikut.

a) Knowing how to yaitu: dapat mengerjakan perhitungan secara rutin atau algoritmik. Tingkat pemahaman ini setara dengan pemahaman mekanikal, pemahaman instrumental, dan pemahaman komputasional.

b) Knowing yaitu: dapat mengerjakan perhitungan dengan sadar akan proses yang dikerjaknnya. Tingkat pemahaman ini setara dengan pemahaman rasional, pemahaman intuitif, dan pemahaman fungsional.

Dari uraian pemahaman matematik di atas, maka dapat di tarik kesimpulan bahwa seseorang dikatakan paham akan konsep matematik jika ia dapat melaksanakan perhitungan rutin atau perhitungan sederhana dengan cara memilih, memanfaatkan atau menggunakan operasi tertentu secara algoritmik, dapat mencoba sesuatu dalam kasus sederhana dan tahu bahwa sesuatu itu berlaku dalam kasus serupa dalam bentuk pemecahan masalah, yang pada intinya ia dapat mengaitkan suatu konsep dengan konsep yang lain secara benar. 
Menurut Sumarmo (2013: 127), secara umum indikator pemahaman matematik meliputi: mengenal, memahami, menerapkan konsep, dan prosedur serta ide matematika. Artinya dalam pembelajaran matematika siswa dituntut untuk memahamai konsep-konsep yang ada di dalamnya. Seorang siswa paham akan konsep matematika dapat dilihat dari cara ia menyampaikan kembali suatu konsep menggunakan dengan bahasanya sendiri tanpa mengurangi kandungan makna di dalamnya, atau ia dapat menggunakan prosedur atau konsep tertentu dalam menjawab pertanyaan.

Berikut ini ada beberapa ciri khusus indikator-indikator soal pemahaman konsep matematik dengan soal untuk aspek penilaian lain berdasar peraturan Dirjen Dikdasmen Depdiknas No 506/C/PP/2004 tanggal 11 November 2004 (Tim PPG Matematika, 2005: 10-12).

1. Kemampuan menyatakan ulang sebuah konsep.

2. Kemampuan mengklasifikasi subjek menurut sifat-sifat tertentu sesuai dengan konsepnya.

3. Mampu memberi contoh dan bukan contoh.

4. Kemampuan menyajikan konsep kedalam berbagai bentuk representasi matematik.

5. Kemampaun mengembangkan syarat perlu atau syarat cukup dari suatu konsep.

6. Kemampuan menggunakan, memanfaatkan dan memilih prosedur tertentu.

7. Kemampuan mengaplikasikan konsep atau algoritma ke pemecahan masalah.

Berdasarkan uraian di atas, maka indikator pemahaman konsep yang digunakan dalam penelitian ini sebagai berikut.

1. Kemampuan menyatakan ulang sebuah konsep.

2. Kemampuan mengklasifikasi subjek menurut sifat-sifat tertentu sesuai dengan konsepnya.

3. Mampu memberi contoh dan bukan contoh.

4. Kemampuan menyajikan konsep kedalam berbagai bentuk representasi matematik.

5. Kemampaun mengembangkan syarat perlu atau syarat cukup dari suatu konsep.

6. Kemampuan menggunakan, memanfaatkan dan memilih prosedur tertentu.

7. Kemampuan mengaplikasikan konsep atau algoritma ke pemecahan masalah.

\section{Pendekatan Kostruktivisme}

Seiring dengan terjadinya perubahan dalam paradigma pendidikan di Indonesia, kegiatan pembelajaran yang berpusat pada guru kini dianggap kurang efektif karena hanya mampu membentuk siswa yang pintar secara teori namun miskin dalam pemahaman dan aplikasinya dalam kehidupan sehari-hari. Hal tersebut kemudian melahirkan konsep pembelajaran yang berpusat pada anak didik (student centered).

Pembaharuan tersebut melahirkan pembaharuan pula dalam segi pendekatan, model, strategi, media hingga evaluasi pembelajaran yang 
digunakan. Salah satu pendekatan yang kegiatannya berpusat pada siswa adalah pendekatan konstruktivisme. Pendekatan ini dilandasi oleh teori belajar konstruktivik yang dikemukakan oleh Jean Piaget.

Bell dan Driver \& Leach (Karli dan Sriyuliatiningsih, 2004:2) mengemukakan bahwa Pendekatan Konstruktivisme adalah salah satu pandangan tentang proses pembelajaran yang menyatakan bahwa dalam proses belajar (perolehan pengetahuan) diawali dengan terjadinya konflik kognitif. Konflik kognitif ini hanya 17ari diatasi melalui pengetahuan diri (self-regulation). Dan pada akhir proses belajar, pengetahuan akan dibangun sendiri oleh anak melalui pengalamannya dari hasil interaktif dengan lingkungannya.

Konflik kognitif yang dimaksud di atas terjadi saat interaksi antara konsepsi awal yang telah dimiliki siswa sebelumnya dengan fenomena atau pengetahuan baru yang diperolehnya melalui kegiatan belajar. Jika hal baru yang diperoleh tidak cocok dengan skema awal anak maka akan terjadi akomodasi sehingga terjadi keseimbangan dan mencapai proses asimilasi. Sedangkan jika hal baru yang diperoleh tersebut sudah cocok dengan skema awal maka akan langsung terjadi proses asimilasi. Kendati demikian tidak menutup kemungkinan siswa akan mengalami "jalan buntu" dalam proses perolehan pengetahuannya, hal ini biasanya terjadi karena ketidakmampuan anak dalam berakomodasi sehingga seorang guru harus mengambil alternatif strategi lain untuk mengatasinya.

Pendekatan konstruktivisme lahir dari teori konstruktivistik yang memandang bahwa dalam proses belajarnya anak telah memiliki konsepsi atau pengetahuan awal yang tidak 17ari diabaikan begitu saja. Keberhasilan belajar yang dicapai siswa tidak hanya bergantung pada situasi dan lingkungan pembelajaran yang diciptakan oleh guru tetapi juga bergantung pada pengetahuan awal yang telah dimiliki anak sebelumnya.

Pendekatan konstruktivisme mensyaratkan suatu proses belajar mengajar yang memungkinkan siswa terlibat aktif secara mental membangun pengetahuannya dengan dilandasi oleh struktur kognitif (skema awal) yang telah dimilikinya. Dalam hal ini guru lebih berperan sebagai fasilitator yang menciptakan lingkungan belajar yang efektif dan menyenangkan sehingga anak dapat bereksplorasi seluas-luasnya dan mencapai hasil belajar yang optimal.

Karli dan Sriyuliatiningsih (2004: 4) mengemukakan hal-hal yang harus diperhatikan oleh seorang guru yang mengajar dengan pendekatan konstruktivisme sebagai berikut.

1) Mengakui adanya konsepsi awal yang dimiliki siswa melalui pengalaman sebelumnya;

2) Menekankan pada kemampuan minds-on dan hands-on;

3) Mengakui bahwa dalam proses pembelajaran terjadi perubahan konseptual;

4) Mengakui bahwa pengetahuan tidak dapat diperoleh secara pasif;

5) Mengutamakan terjadinya interaksi sosial. 
Seperti halnya pendekatan yang lain, pendekatan konstruktivisme juga memiliki langkah-langkah atau fase-fase tertentu yang membedakannya dengan pembelajaran yang lain. Langkah-langkah tersebut sebagaimana diungkapkan Karli dan Sriyuliatiningsih (2004: 5) adalah sebagai berikut:

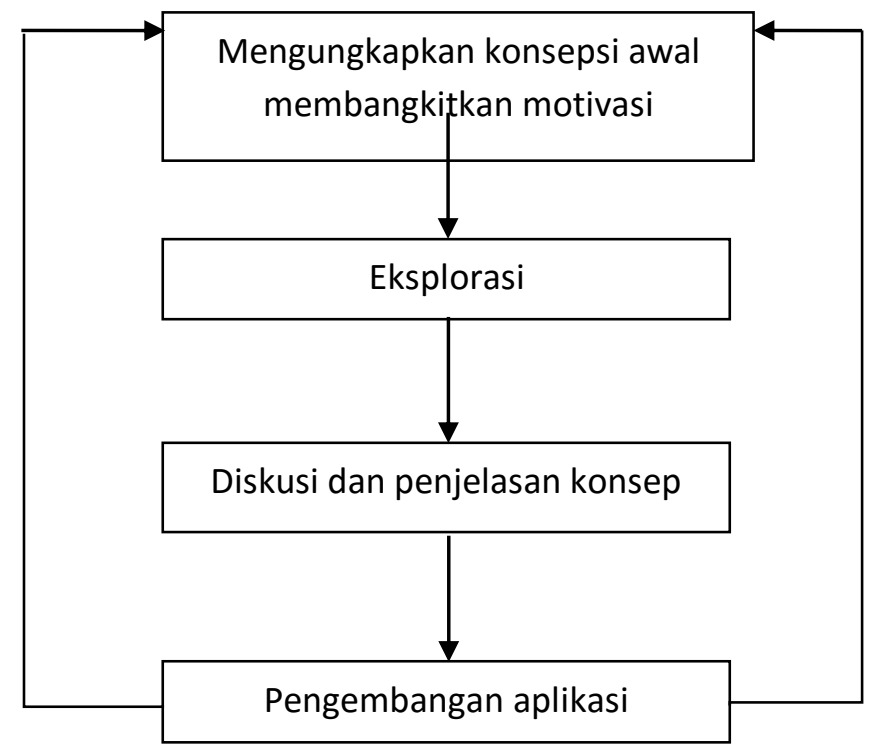

Gambar 1: Alur Pendekatan Konstruktivisme

(Karli dan Sriyuliatiningsih, 2004:5)

\section{METODE PENELITIAN}

Metode penelitian yang digunakan dalam penelitian ini adalah metode kuasi eksperimen. Pada kuasi eksperimen ini, subjek tidak dikelompokkan secara acak, tetapi peneliti menerima keadaan subjek apa adanya, (Ruseffendi, 2003). Adapun desain penelitian yang dilakukan pada penelitian ini adalah pretest-posttest control group design. Ilustrasi desain penelitiannya sebagai berikut:

$\begin{array}{cccc}\text { Kelompok } & \text { Pretest } & \text { Perlakuan } & \text { Posttest } \\ \text { Eksperimen } & \text { T1 } & \text { X } & \text { T2 } \\ \text { Kontrol } & \text { T1 } & . & \text { T2 }\end{array}$

Adapun yang menjadi populasi dalam penelitian ini adalah seluruh siswa SMP Negeri 3 Sumedang. Sampel penelitian ini diambil secara purposive sampling sebanyak dua kelas dari delapan kelas yang ada di SMP tersebut. Satu kelas untuk kelas eksperimen yang pembelajarannya menggunakan pendekatan konstruktivisme dan satu kelas lagi sebagai kelas Kontrol yang pembelajarannya secara konvensional.

Penelitian ini memuat dua variabel, yaitu variabel terikat dan variabel bebas.Variabel bebas yang digunakan dalam penelitian ini adalah pembelajaran dengan menggunakan pendekatan konstruktivisme.. Variabel 
terikat dalam penelitian ini yaitu kemampuan pemahaman konsep matematis siswa.

\section{HASIL PENELITIAN}

Data yang diperoleh dari siswa melalui tes digunakan untuk mengetahui pengaruh pembelajaran yang dilakukan terhadap peningkatan kemampuan pemahaman konsep matematis. Peningkatan kemampuan pemahaman konsep matematis yang dicapai oleh siswa dapat dilihat dari data gain ternormalisasi. Gain Ternormalisasi ( $\mathrm{N}$ Gains) diperoleh dengan formulasi Hake. Hipotesis statistik yang akan diuji adalah:

$\mathrm{H}_{0}: \mu_{1}=\mu_{2}$

$\mathrm{H}_{1}: \mu_{1}>\mu_{2}$

Perhitungan uji perbedaan dua rerata $\mathrm{N}$-Gains pada taraf signifikansi $\alpha$ $=0,05$ rangkumannya disajikan pada Tabel di bawah.

Tabel 1 Ringkasan Analisi Data N Gains

\begin{tabular}{|c|c|c|c|c|}
\hline Kelas & $\mathbf{n}$ & $\overline{\boldsymbol{x}}$ & $\mathbf{t}_{\text {hitung }}$ & $\mathbf{t}_{\text {tabel }}$ \\
\cline { 1 - 3 } Eksperimen & 21 & 0,55 & \multirow{2}{*}{2,16} & 2,02 \\
\hline Kontrol & 21 & 0.39 & & \\
\hline
\end{tabular}

Perhitungan uji dua rerata dependen dilakukan pada taraf signifikansi $\alpha=0,05$ menunjukkan bahwa $t_{\text {hitung }}(2,16)$ lebih besar dari $t_{\text {tabel }}(2,02)$, sehingga dapat disimpulkan bahwa $\mathrm{H}_{0}$ ditolak. Artinya kemampuan pemahaman konsep siswa kelas eksperimen lebih baik dari pada siswa kelas kontrol.

Pembelajaran dengan pendekatan konstruktivisme memberikan pengaruh terhadap kemampuan pemahaman konsep matematis. Hal ini terjadi karena fase-fase dari model konstruktivisme yang ada telah membuat siswa belajar matematika dengan mengkonstruksi pengetahuan mereka sendiri mengenai konsep yang dipelajari. Hal ini sejalan dengan pendapat Piaget (Sumantri dan Permana, 1998:17) bahwa Anak adalah seorang yang aktif, membentuk atau menyusun pengetahuan mereka sendiri, pada saat mereka menyesuaikan pikirannya sebagaimana terjadi ketika mereka mengeksplorasi lingkungan dan kemudian tumbuh secara kognitif terhadap pemikiranpemikiran yang logis.

Dengan proses pembelajaran yang dilalui siswa dengan mengkonstruksi pengetahuannya sendiri diharapkan konsep yang dipelajari akan lebih kuat tertanam dalam benak siswa sehingga tidak mudah terlupakan dan siswa pun dapat mengaplikasikan konsep yang dipelajarinya tersebut dalam menghadapi masalah-masalah yang ditemui dalam kehidupan seharihari.

\section{E. KESIMPULAN DAN SARAN}

\section{Kesimpulan}

Berdasarkan hasil penelitian, diperoleh beberapa hal yang dapat disimpulkan tentang Penggunaan pembelajaran menggunakan Pendekatan Konstruktivisme dalam Upaya Meningkatkan Kemampuan Pemahaman 
Konsep Matematis Siswa. Adapun kesimpulan tersebut sebagai berikut kemampuan pemahaman konsep matematis siswa yang pembelajarannya menggunakan pendekatan konstruktivisme lebih baik dari pada siswa yang memperoleh pembelajaran biasa.

\section{Saran}

Berdasarkan beberapa temuan yang diperoleh dari penelitian ini, maka penulis dapat mengemukakan saran berikut. Pembelajaran dengan menggunakanpendekatan konstruktivisme berpengaruh terhadap kemampuan pemahaman konsep matematis, yang berakibat pada peningkatan prestasi belajar siswa. Namun pada pendekatan ini peran siswa sebagai fasilitator harus selalu diperhatikan oleh guru jangan sampai siswa mengkonstruksi konsep yang keliru.

\section{F. DAFTAR PUSTAKA}

Karli, Hilda dan Sriyuliatiningsih, Margaretha. 2004. Implementasi Kurikulum Berbasis Kompetensi. Bandung: Bina Media Informasi.

Ruseffendi. (2003). Dasar-Dasar Penelitian Pendidikan dan Bidang Eksakta Lainnya. Bandung: PT. Tarsito.

Sumantri, Mulyani dan Permana, Johar. 1998. Strategi Belajar Mengajar. Jakarta: Depdikbud.

Sumarmo, U. (2013). Kumpulan Makalah Berpikir dan Disposisi Matematik Beserta Pembelajarannya. Bandung: FPMIPA UPI.

Suwangsih, Erna dan Tiurlina. 2006. Model Pembelajaran Matematika. Bandung: UPI PRESS.

Tim PPPG Matematika. (2005). Prinsip Dasar Penilaian dan Penyusunan Perangkat. Yogyakarta:Dirjen Dikdasmen Depdiknas PPPG Matematika. 